\title{
RECURRENT MENINGITIS IN A CASE OF CONGENITAL ANTERIOR SACRAL MENINGOCELE AND AGENESIS OF SACRAL AND COCCYGEAL VERTEBRAE
}

\author{
CAROLINA A. R. FUNAYAMA*, MARLENE DE F. TURCATO*, RENATO MOURA-RIBEIRO*, \\ GUTEMBERG M. ROCHA*, JOÃOM. PINA NETO*, MARIA VALERIANA L. MOURA-RIBEIRO* *
}

SUMMARY - A rare case of recurrent meningitis due to congenital anterior sacral meningocele and agenesis of the sacral and coccygeal vertebrae is described. An autosomal dominant inheritance is demonstrated for lower cord malformation, and environmental factors (chromic acid or fumes) are discussed.

KEY WORDS: recurrent meningitis, neural tube defects, inherited diseases.

Meningite recorrente em um paciente com meningocele sacral anterior e agenesia sacral e coccigea

RESUMO - Um caso raro de meningite recorrente devido a meningocele sacral anterior e agenesia das vértebras sacras coccígeas é descrito. Herança autossômica dominante para malformação medular caudal é demonstrada e. possiveis fatores ambientais (ligados ao cromo), são discutidos.

PALAVRAS - CHAVE: meningite recorrente, malformação do tubo neural, doenças hereditárias.

Recurrent meningitis is a condition due to, among other causes, cerebrospinal fluid (CSF) fistulae through structures like the cribriform plate, stapedial footplate and spinal cord, which develops from congenital defects, infections, infiltrative tumors, traumas or surgeries.

We report a rare case of recurrent meningitis related to congenital anterior sacral meningocele and agenesis of the sacral and coccygeal vertebrae.

\section{CASE REPORT}

SS, a one year old healthy white male infant, became feverish 35 days before admission. Otitis was diagnosed and amoxicillin prescribed. After a 13 day course, the fever continued and the patient became irritable. Bacterial meningitis was diagnosed on the basis of the remarkable number of polymorphonuclear leukocytes/ $\mathrm{mm}^{3}$ in the CSF and normal brain computerized tomography (CT). No microoganisms were identified by anaerobic or aerobic cultures. Treatment with ampicillin was then started. This was his second episode of bacterial meningitis. The first occurred at 4 months of age, when the patient was seen at another hospital, and improved within two weeks. No germ was detected in the first episode, probably due to the administration of a systemic antibiotic for

\footnotetext{
*São Paulo University, Ribeirão Preto, Brazil; ** Campinas University, Brazil Aceite: 9-agosto-1995.
}

Dra. Carolina A.R. Funayama - Departamento de Neurologia, Psiquiatria e Psicologia Médica - Hospital das Clínicas, Faculdade de Medicina de Ribeirāo Preto, Unversidade de Sāo Paulo - 14048-900 Ribeirão Preto SP - Brasil. FAX 55.16.6330866. 
otitis as in this second episode. Upon admission to our hospital the neuromotor development, general and neurological examination of the patient were unremarkable. No sign of sinus derma was detected. A progressive state of decreased consciousness was observed and intractable focal, erratic convulsions appeared. A brain CT showed signs of ventriculitis and a ventricular puncture confirmed pyogenic ventriculitis. Again, the germ was not isolated. Cefotaxime was given and a ventricular reservoir was installed to relieve intracranial hypertension. Cisternal scintillography and polytomography of middle ear, cribriform plate and anterior cranial fossa were negative. After 45 days the patient was discharged from the hospital, with normal CSF, tetraspasticity, poor visual and auditive perception. Two months after discharge he developed a new episode of pyogenic meningitis. Two days before admission his mother had observed sacral swelling and flaccidity of the lower limbs. This time Proteus mirabilis and Klebsiella pneumoniae were identified by CSF culture. Spinal Cord X-rays and myelotomography demonstrated lack of all sacral and coccygeal vertebrae and anterior sacral meningocele. The patient died one month after admission, presenting a severe meningeal infection and sepsis. Autopsy confirmed these malformations and revealed a sacral intraspinal abscess. No other malformations were detected.

The patient's parents had 6 children, no abortions. The father emigrated to Brazil from Austria and the mother is Brazilian. In Brazil the father works as a tanner, the same occupation of his family in Austria. The first two children are males, the third and sixth were females born at term who died during the neonatal period of respiratory problems and gastric haemorrhage, respectively. One female presented some signs of mongolism (a chromosome study was not performed), and neither showed clinical signs of spina bifida. The fourth was the patient; the fifth, a male. We examined the parents and their sons. All were healthy, with no clinical signs of neural tube defects by physical examination. Spinal Cord X-rays were performed, revealing: spina bifida at the L5 and sacral levels and grade I spondylolisthesis of L5 over S1 in the father, age 56; spina bifida at the sacral level in the mother, age 49, and in the eldest son, 25; normal in the second son, 23; and spina bifida at the L5 and sacral levels in the youngest son, 9 years old.

\section{COMMENTS}

Besides the fact that this is a rare condition, the difficulty in finding the cause of recurrent meningitis in this case was due to recurrent infections in the middle ear. The use of a systemic antibiotic prior to meningitis probably accounted for the negative cultures in the first and second episodes. This fact led us to search for fistulae at cranial sites, postponing the cord investigation. The route of entry of the germ into the nervous system did not become clear in this case.No neurenteric or skin fistula were detected. Anterior sacral meningocele is a rare condition that may be associated with agenesis or malformation of sacral and coccygeal vertebrae. It was first described by Bryant ${ }^{1}$, in 1837 , and until the 1970 decade an X-linked dominant inheritance was suggested, since most examined cases were women, due to association with genital malformation in females. Say et al. ${ }^{5}$ reported a family in whom two males were stillborn with severe malformations, suggesting that the hemizygous state in the male could be lethal. Fineman et al. ${ }^{2}$ described four families with spinal dysraphia and proposed an autosomal dominant inheritance. This same pattern of inheritance was observed by Yates et al. ${ }^{8}$ who reported a family in whom at least 11 individuals of three generations had partial sacral agenesis and have had either anterior sacral meningoceles, teratomas or both. We could not perform MRI for a better study of our patient's family, but the presence of spina bifida in all family members but one supports the proposal of autosomal dominant inheritance. The presence of the spina bifida in both parents is interesting. Although statistics about the prevalence of this malformation in our region are not available, we have observed it frequently, a fact probably explaning this concomitance. On the other hand, sacral agenesis is rare, and we may propose that environmental factors might have been important in this case. The father is from an European family who worked with leather in the old country and continued to do so in Brazil, with exposure to chromic acid or fumes. We did not find reference to the association of sacral agenesis with chronic intoxication with chrome.

In a review of the literature on English language papers between January, 1990 and March, 1994 we found few reports associating recurrent meningitis with neural tube malformation ${ }^{4,6,7}$ and only one associated with anterior sacral meningoceles. Although cord malformations are rarely associated with recurrent meningitis, their possible presence should be investigated even without subcutaneous or skin signs, after excluding CSF fistulae at cranial sites. In addition, when the cord malformation is diagnosed it is important to investigate the patient's family. 


\section{REFERENCES}

1. Bryant T. Case of deficiency of the anterior part of the sacrum with a thecal sac in the pelvis, similar to the tumor of spina bifida. Lancet 1837, 1:358.

2. Fineman RM, Jorde LB, Martin RA et al. Spinal dysraphia as an autosomal dominant defect in four families. Am J Med Genet 1982, 12:457-464.

3. Gumerlock MK, Spollen LE, Nelson MJ, Bishop RC, Coorperstock MS. Cervical neurenteric fistula causing recurrent meningitis in Klippel-Feil sequence. Pediatr Infect Dis J 1991, 10:532-535.

4. Kohler T, Wiedersberg $H$, Bollmann L. Nasal encephalocele as a cause of recurrent bacterial meningitis. Monatsschr Kinderheilkd 1991, 39:783-785.

5. Lisukova TE, Galina MV, Kashin AM. Recurrent meningitis as a complication of anterior sacral meningocele with rectal fistula. Klin Med (Mosk) 1991, Nov 9:92-93.

6. Say B, Carpenter NJ, Coldwell JG. Anterior sacral meningocele. JAMA 1977, 237:2602.

7. Silbert $\mathrm{P}$, McCornish $\mathrm{M}$, Chakeva $\mathrm{T}$, Surveyor I. Intranasal meningoencephalocele causing recurrent meningitis in a 25-year-old caucasian man. Med J Aust 1992, 156:141-142

8. Yates VD, Wilroy RS, Whitington GL, Simmons JCH. Anterior sacral defects: an autosomal dominantly inherited condition. J Pediatr 1983, 102:239-242. 